\title{
Pengaruh Rasio BOPO, Modal Intelektual, Dan Pengungkapan Corporate Social Responsibility Pada Profitabilitas Perusahaan Perbankan
}

\author{
Putu Nesy Swendriani ${ }^{1}$ \\ Luh Gede Krisna Dewi ${ }^{2}$ \\ ${ }^{1,2}$ Fakultas Ekonomi dan Bisnis Universitas Udayana (Unud), Bali, Indonesia \\ e-mail: nswendriani@gmail.com
}

\begin{abstract}
ABSTRAK
Penelitian ini bertujuan untuk memperoleh bukti empiris pengaruh rasio BOPO, modal intelektual, dan pengungkapan corporate social responsibility (CSR) pada profitabilitas perusahaan perbankan. Penelitian ini dilakukan pada perusahaan perbankan yang terdaftar di Bursa Efek Indonesia (BEI) periode 2013-2017. Sampel ditentukan melalui metode non probability sampling dengan teknik purposive sampling. Jumlah sampel yang digunakan dalam penelitian ini berjumlah 60 sampel amatan. Teknik analisis data yang digunakan adalah analisis regresi linear berganda. Hasil dari penelitian ini menunjukkan bahwa rasio BOPO berpengaruh negatif pada profitabilitas perusahaan perbankan. Hasil penelitian ini juga menunjukkan bahwa modal intelektual dan pengungkapan CSR tidak berpengaruh pada profitabilitas perusahaan perbankan. Implikasi penelitian secara teoritis membuktikan teori stakeholder, teori legitimasi, dan teori resource-based dalam menjelaskan efisiensi operasional perusahaan perbankan.
\end{abstract}

Kata kunci: BOPO, modal intelektual, CSR, profitabilitas.

\begin{abstract}
This study aims to obtain empirical evidence of the effect of BOPO ratio, intellectual capital, and corporate social responsibility (CSR) disclosure on profitability of banking companies. Research conducted on banking companies on the Indonesia Stock Exchange (IDX) for the 2013-2017 period. The sample is determined through non probability sampling method with purposive sampling technique. The number of samples used in this study were 60 observation samples. The data analysis technique used is the analysis of multiple linear regression analysis. The results of this study indicate that $B O P O$ ratio show a negative effect on profitability of banking companies. The results also show that intellectual capital and CSR disclosure doesn't affect the probability of banking companies. The research implications theoretically prove stakeholder theory, legitimacy theory, and resource-based theory in explaining the operational efficiency of banking companies.
\end{abstract}

Keywords: BOPO, intellectual capital, CSR, profitability.

\section{PENDAHULUAN}

Bank merupakan satu diantara lembaga keuangan yang ada di Indonesia. Berdasarkan Undang-Undang RI No. 10 Tahun 1998 tanggal 10 November 1998 tentang Perbankan, yang dimaksud dengan bank adalah lembaga intermediasi atau perantara keuangan yang menghimpun dana dari masyarakat dalam bentuk 
simpanan dan menyalurkannya kepada masyarakat dalam bentuk kredit atau bentuk-bentuk lainnya guna meningkatkan taraf hidup dan kesejahteraan masyarakat.

Dari pengertian tersebut, menunjukkan bahwa kegiatan bank memiliki tujuan untuk memperoleh keuntungan optimal dengan memberikan jasa keuangan kepada masyarakat. Dengan demikian, bank harus menjaga kepercayaan masyarakat dengan memperhatikan kelancaran pihak yang memerlukan dana dalam memenuhi kewajibannya untuk mencapai profitabilitas yang tinggi. Profitabilitas merupakan indikator yang paling tepat untuk mengukur keberhasilan pengelolaan bank (Sofiyan, 2013: 39).

Dewasa ini, perekonomian di Indonesia mengalami pasang surut. Hal tersebut disebabkan karena adanya persaingan ketat di era globalisasi dan pasar bebas kancah internasional. Otoritas Jasa Keuangan (OJK) mencatat suku bunga kredit perbankan Indonesia mencapai kisaran 11,25-13,30 persen pada korporasi dan 16-23 persen pada kredit mikro. Sementara rata-rata suku bunga kredit di Malaysia, Singapura, dan Thailand mencapai kisaran 3-7 persen (www.sindonews.com). Hal tersebut berarti ada selisih tingkat bunga kredit perusahaan perbankan Indonesia hingga empat kali lebih besar jika dibandingkan negara-negara tetangga. Tingginya suku bunga kredit perusahaan perbankan akan meningkatkan biaya produksi perusahaan sehingga akan menurunkan daya saing produk lokal dalam perdagangan internasional. Direktur Biro Riset Infobank mengungkapkan pula bahwa bank-bank akan menaikkan suku bunga sebagai antisipasi untuk mempertahankan selisih tingkat bunga kredit yang berdampak 
pada meningkatnya risiko kredit bermasalah. Oleh sebab itu, bank harus meningkatkan strategi operasional bank guna mencegah terjadinya ketidakseimbangan fungsi intermediasi yang mana dalam satu sisi perusahaan perbankan sukses dalam mengumpulkan dana masyarakat namun di sisi lain penyaluran kredit kepada masyarakat mengalami penurunan.

Profitabilitas bank adalah kemampuan perusahaan memperoleh laba sebagai gambaran tingkat keberhasilan yang dapat dicapai oleh bank dalam kegiatan operasionalnya (Winarno dkk., 2015). Rasio return on assets (ROA) sebagai pengukuran profitabilitas bank didukung oleh Bank Indonesia sebagai pembina dan pengawas perusahaan perbankan lebih mengutamakan nilai profitabilitas yang diukur dari aset pada sebagian besar dana simpanan masyarakat.

Tabel 1.

Rata-rata Return on Assets (ROA), Suku Bunga, dan Dana Kelola Perusahaan Perbankan pada Bank Umum Konvensional Periode 2012-2017

\begin{tabular}{cccccc}
\hline No. & Tahun & $\begin{array}{c}\text { ROA } \\
(\%)\end{array}$ & $\begin{array}{c}\text { Suku Bunga } \\
(\%)\end{array}$ & Penyaluran Dana & Sumber Dana \\
\cline { 5 - 6 } & & 3,18 & 10,71 & 3.795 .574 & 3.240 .845 \\
2 & 2012 & 10,28 & 4.431 .384 & 3.744 .761 \\
3 & 2013 & 3,04 & 12,49 & 5.084 .045 & 4.242 .481 \\
4 & 2014 & 2,91 & 13,04 & 5.792 .205 & 4.811 .126 \\
5 & 2016 & 2,43 & 12,05 & 5.689 .968 & 5.512 .490 \\
6 & 2017 & 2,46 & 10,86 & 6.826 .541 & 5.606 .788 \\
\hline \multicolumn{2}{r}{ Sumber: }
\end{tabular}

Berdasarkan Tabel 1 menunjukkan bahwa perkembangan rata-rata ROA dan suku bunga perbankan tergolong fluktuatif serta ketidakseimbangan dana kelola sebagai fenomena ekonomi yang menarik perhatian. Penurunan ROA mengindikasikan kemampuan manajemen bank dalam hal mengelola aktiva untuk meningkatkan pendapatan dan/atau menekan biaya tersebut menurun dan terdapat 
indikasi risiko kredit bermasalah yang tinggi. Selain itu, ROA mengalami kenaikan yang menunjukkan kemampuan bank yang baik dalam mengoptimalkan produktivitas aset dan pertumbuhan kredit yang lebih baik.

Suku bunga yang fluktuatif mengindikasikan bahwa stabilitas tingkat bunga kredit masih kurang dan kurang stabilnya jumlah minat masyarakat terhadap perusahaan perbankan baik menabung ataupun melakukan peminjaman. Semakin rendah suku bunga, maka semakin tinggi profitabilitas perusahaan perbankan yang diperoleh. Ketidakseimbangan dana kelola menunjukkan adanya peningkatan pada sumber dana, namun penyaluran dana perusahaan perbankan tergolong fluktuatif. Hal tersebut membuktikan bahwa perusahaan perbankan mengalami ketidakseimbangan fungsi intermediasi yang pada satu sisi dapat mengumpulkan dana masyarakat, namun di sisi lain penyaluran kredit kepada masyarakat mengalami penurunan.

Berdasarkan fenomena profitabilitas perusahaan perbankan, rasio BOPO akan memberikan gambaran efisiensi operasional perusahaan perbankan sebagai sebuah permasalahan yang sangat mendasar untuk dipecahkan karena efisiensi tersebut akan berpengaruh langsung pada profitabilitas dan struktur kekuatan permodalan bank. Bank yang dalam usahanya tidak efisien pada penggunaan biaya operasional dan pendapatan operasional akan mengakibatkan ketidakmampuan bersaing dalam mengatur dana masyarakat maupun menyalurkan dana sebagai modal usaha. Apabila lembaga perbankan memiliki efisiensi operasional terutama efisiensi biaya maka akan diperoleh keuntungan yang optimal, biaya lebih kompetitif, peningkatan jumlah penyaluran dana, 
peningkatan pelayanan nasabah, penguatan keamanan, dan kesehatan perusahaan perbankan yang meningkat.

Berdasarkan fenomena fluktuasi ROA sebagai indikator pengukuran profitabilitas bank, di era ekonomi global dan modern saat ini, upaya yang dilakukan adalah melakukan inovasi dalam suatu bisnis dan memiliki keunggulan kompetitif. Persaingan bisnis yang sangat ketat mengakibatkan banyak perusahaan mengubah sistem usaha yang awalnya berbasis tenaga kerja (labor-based business) menjadi berbasis pengetahuan (knowledge-based business). Penerapan knowledge-based business pada perusahaan menciptakan cara pengelolaan pengetahuan untuk sarana pencapaian tujuan perusahaan dalam memperoleh pendapatan perusahaan dengan karakteristik penerapan manajemen pengetahuan (knowledge management), dengan keberhasilan suatu perusahaan yang berkaitan pada suatu penciptaan transformasi dan kapitalisasi dari pengetahuan itu sendiri.

Pandangan ekonomi yang berubah menjadi ekonomi berbasis pengetahuan menyebabkan pengelolaan aset tidak berwujud menjadi perhatian untuk ditingkatkan (Fariana, 2014). Aset yang berharga, tidak dapat disubtitusikan, langka, dan sulit ditiru disebut aset tidak berwujud yang menjadi strategis keberlanjutan untuk keunggulan kompetitif dan kinerja keuangan.

Pendekatan yang digunakan dalam penilaian dan pengukuran aset pengetahuan satu diantaranya adalah modal intelektual, namun belum memiliki ketetapan pengukuran yang tepat (Baroroh, 2013). Manajemen efisiensi modal intelektual merupakan proses yang kompleks, karena memiliki hubungan pada masalah identifikasi dan pengukuran (Kweh et al., 2013). Pulic (1998) dalam 
Ulum dkk. (2008) tidak secara langsung mengukur modal intelektual perusahaan, tetapi memberikan pendapat mengenai ukuran untuk mengukur efisiensi dari nilai tambah adanya keahlian intelektual perusahaan (value added intellectual coefficient-VAIC $\left.{ }^{\mathrm{TM}}\right)$. Pengukuran $\mathrm{VAIC}^{\mathrm{TM}}$ memiliki tiga komponen utama yang terdiri dari value added capital employed (VACE) yang menunjukkan physical capital, value added human capital (VAHC) yang menunjukkan human capital, dan value added structural capital (VASC) yang menunjukkan structural capital. Menurut MERITUM project 2001 dalam Lentjushenkova dan Lapina (2014) pengertian modal intelektual lebih sederhana yaitu kombinasi dari sumber daya manusia, organisasi, dan relasi perusahaan.

Untara dan Mildawati (2014) menyatakan bahwa sumber daya manusia yang berkualitas menjadi hal penting untuk dapat menghadapi suatu persaingan. Modal intelektual merupakan salah satu aset strategik yang penting dalam pengetahuan berbasis ekonomi (Rehman et al., 2011). Fenomena modal intelektual di Indonesia mulai berkembang setelah munculnya Pernyataan Standar Akuntansi Keuangan (PSAK) No. 19 (revisi 2000) tentang Aktiva Tidak Berwujud (Maesaroh dan Rahayu, 2015).

Teknologi informasi dan pengetahuan pada perkembangan new economy mengakibatkan terjadi peningkatan modal intelektual sebagai alat ukur dalam menentukan kinerja keuangan perusahaan khususnya laba perusahaan. Keberhasilan perusahaan tidak hanya dilihat dari kinerja yang dapat diukur melalui rasio keuangan perusahaan pada saat ini, namun sumber daya hendaknya dapat menghasilkan profitabilitas yang terus meningkat, sehingga kelangsungan 
hidup perusahaan dapat terjamin. Pentingnya kelangsungan hidup perusahaan perlu dipertimbangkan, selain rasio BOPO dan modal intelektual yang mewakili kualitas sumber daya perusahaan dalam hal ini merupakan faktor internal, perusahaan perlu memperhatikan faktor eksternal yaitu kepentingan publik dalam mengembangkan hubungan sosial yang merupakan tanggung jawab sosial perusahaan kepada stakeholders. Tanggung jawab sosial ini disebut dengan corporate social responsibility (CSR).

Isu penting yang mendorong adanya kebijakan memberlakukan CSR saat ini dilatarbelakangi oleh keberadaan perusahaan yang memiliki pengaruh secara langsung maupun tidak langsung terhadap keberlangsungan usaha di suatu wilayah dan dituntut untuk mendatangkan kesejahteraan masyarakat, bukan sebaliknya merugikan masyarakat sekitar. CSR merupakan sarana pengelolaan usaha bagi perusahaan selain untuk kepentingan para pemegang saham (shareholder) tetapi juga untuk pihak-pihak luar perusahaan (stakeholder) seperti lingkungan, pemerintah, lembaga swadaya masyarakat (LSM), para pekerja, dan komunitas lokal.

Dunia perbankan di Indonesia mulai menunjukkan perhatiannya terhadap masalah lingkungan melalui berbagai kegiatan perusahaan perbankan yang dikenal dengan green banking. Bank yang "green" akan memadukan nature, wellbeing, economy dan society ke dalam prinsip bisnis yang memperhatikan ekosistem dan kualitas hidup manusia. Hal tersebut akan memberikan output berupa efisiensi biaya operasional perusahaan, keungulan kompetitif, corporate identity, dan brand image yang kuat, serta pencapaian target bisnis yang seimbang 
(World Bank Group, 2010 dalam Suryaman, 2016). Bulan Juli 2017, OJK merilis peraturan keuangan berkelanjutan untuk memberikan panduan "green" pada seluruh sistem keuangan, termasuk perbankan, pasar modal, asuransi, leasing, dan dana pensiun (www.ifc.org).

Globalisasi dan peningkatan jumlah perusahaan perbankan menyebabkan standar CSR menjadi salah satu persyaratan dalam bisnis di negara-negara berkembang (Ngoc, 2018). Pentingnya perusahaan melakukan pengungkapan CSR yaitu untuk membangun reputasi dan citra positif perusahaan (Bhernadha dkk., 2017). Namun, perusahaan cenderung mengabaikan tanggung jawab sosial tersebut karena stakeholder dianggap tidak memberikan kontribusi pada kelangsungan hidup perusahaan. Selain itu, hal ini juga dikarenakan awal dari budaya perusahaan adalah berpijak pada single bottom line yaitu memaksimalkan keuntungan (profit) dan apabila perusahaan melaksanakan pengungkapan tanggung jawab sosial, maka perusahaan menilai hal tersebut akan menambah biaya yang mengurangi pembagian keuntungan.

Berdasarkan tinjauan penelitian terdahulu terkait ketiga variabel dalam penelitian ini yaitu pertama, variabel rasio BOPO masih memberikan hasil yang tidak konsisten terhadap profitabilitas perusahaan. Penelitian Yogi dan Ramantha (2013) serta Lia dan Erawati (2015) menunjukkan rasio BOPO berpengaruh negatif pada profitabilitas. Hasil yang berbeda ditunjukkan oleh hasil penelitian Limpaphayom dan Polwitoon (2004) yang menyatakan bahwa tidak ada pengaruh antara rasio BOPO dengan ROA dan menurut Harfiah et al. (2016), rasio BOPO berpengaruh positif signifikan terhadap ROA. 
Kedua, variabel modal intelektual juga memberikan hasil yang tidak konsisten terhadap profitabilitas perusahaan. Menurut Puspitosari (2016), modal intelektual berpengaruh positif terhadap ROA. Beberapa penelitian di berbagai negara yang berfokus pada ROA yang dipengaruhi oleh modal intelektual serta menggunakan model VAIC ${ }^{\text {TM }}$ antara lain di Singapura (Tan et al., 2007), Malaysia (Khalique et al., 2013), Indonesia (Ciptaningsih, 2013) dan (Salim dan Karyawati, 2013), Turki (Ozkan et al., 2016), serta Serbia (Bontis et al., 2015). Penelitian-penelitian tersebut menunjukkan adanya perbedaan hasil penelitian yang diperoleh.

Ketiga, variabel pengungkapan CSR yang memberikan hasil yang tidak konsisten terhadap profitabilitas perusahaan pula. Pada penelitian Bhernadha dkk. (2017) menyatakan bahwa variabel pengungkapan CSR berpengaruh positif terhadap ROA. Namun ada juga penelitian yang menunjukkan bahwa pengungkapan CSR tidak berpengaruh terhadap semua rasio keuangan yang digunakan baik ROA, ROE, dan EPS (Yaparto dkk., 2013). Selain itu, pengungkapan CSR tidak berpengaruh terhadap profitabilitas perusahaan perbankan (Mustafa dan Handayani 2014). Penelitian Sari dkk. (2016) menyatakan pengungkapan CSR berpengaruh negatif pada ROA.

Berdasarkan uraian latar belakang, fenomena, dan adanya hasil penelitian yang belum konsisten di atas, maka membuka peluang untuk dilakukannya penelitian kembali, dengan mengambil judul "Pengaruh Rasio BOPO, Modal Intelektual, dan Pengungkapan Corporate Social Responsibility pada Profitabilitas Perusahaan Perbankan.” Perusahaan perbankan digunakan dalam penelitian ini 
karena sesuai dengan fenomena latar belakang masalah penelitian, ROA, suku bunga, dan dana kelola pada bank mengalami fluktuasi, serta tugas manusia dalam perusahaan perbankan yang sangat vital, sehingga dibutuhkan kualitas sumber daya manusia yang tinggi. Perusahaan perbankan merupakan satu diantara subsektor dengan modal intelektual yang intensif dan ditinjau dari keseluruhan aspek intelektual, perusahaan perbankan memiliki karyawan yang lebih homogen daripada subsektor ekonomi lainnya. Teori yang digunakan dalam penelitian ini yaitu teori stakeholder, teori legitimasi, dan teori resource-based.

Tahun 1984, Freeman menyatakan bahwa teori stakeholder dianggap menjadi paradigma dominan untuk memperkuat konsep bahwa perusahaan selain bertanggung jawab kepada pemegang saham, perusahaan juga bertanggung jawab kepada para stakeholder. Teori stakeholder menjelaskan bahwa rasio BOPO, modal intelektual, dan pengungkapan corporate social responsibility (CSR) merupakan upaya pelaporan agar memberikan informasi yang lengkap kepada pihak-pihak yang berkepentingan (stakeholder).

Legitimasi merupakan sebuah pengakuan akan legalitas sesuatu. Teori ini menganjurkan perusahaan untuk meyakinkan bahwa aktivitas dan kinerjanya dapat diterima oleh masyarakat. Menurut O’Donovan (2002) mengatakan bahwa legitimasi organisasi dapat dilihat sebagai sesuatu yang diberikan masyarakat kepada perusahaan dan sesuatu yang diinginkan atau dicari perusahaan dari masyarakat. Teori legitimasi dan teori stakeholder merupakan perspektif teori yang berada dalam kerangka teori ekonomi politik (Gray et al., 1995). Teori legitimasi juga memberikan perspektif yang komprehensif pada rasio BOPO, 
modal intelektual, dan pengungkapan corporate social responsibility (CSR) dalam laporan tahunan perusahaan.

Teori resource-based dipelopori oleh Penrose (1959) yang mengemukakan bahwa sumber daya perusahaan tergolong heterogen, produktivitas sumber daya perusahaan akan menciptakan karakter unik bagi tiap-tiap perusahaan. Teori resource-based adalah suatu gagasan dalam teori manajemen strategik dan keunggulan kompetitif perusahaan yang menyatakan bahwa sumber daya yang unggul dari perusahaan akan mencapai suatu keunggulan (Solikhah et al., 2010). Secara spesifik DeSarbo et al. (2005) menyatakan bahwa pengaruh strategi terhadap kinerja perusahaan ditentukan oleh lingkungan dan kapabilitas. Menurut Jackson dan Schuler (1995) teori ini menjelaskan sumber daya dibagi menjadi tiga yaitu sumber daya fisik, sumber daya manusia, dan sumber daya organisasional. Pada teori ini, pandangan yang berorientasi pada sumber daya akan ditunjukkan pula pada efisiensi operasional perusahaan yakni cara mengelola biaya operasional dan pendapatan operasional (BOPO) perusahaan dan pengembangan modal intelektual.

Rasio BOPO merupakan ukuran bagi efisiensi perusahaan perbankan yang diperoleh dari perbandingan biaya operasional dengan pendapatan operasional. Tingkat efisiensi adalah pengukuran seberapa besar kemampuan bank dalam melakukan kegiatan operasionalnya. Rasio BOPO akan mempengaruhi profitabilitas bank dengan menunjukkan penggunaan semua faktor produksi bank dengan tepat guna dan tepat hasil (Nursatyani, 2011). Semakin kecil rasio BOPO, 
maka semakin meningkat profitabilitas suatu bank. Sebaliknya, semakin besar rasio BOPO, maka semakin menurun profitabilitas suatu bank.

Rasio BOPO mempunyai hubungan yang negatif terhadap ROA, yang berarti bahwa apabila rasio BOPO meningkat, maka ROA yang diperoleh oleh perusahaan perbankan akan menurun. Hal ini disebabkan karena dalam menjalankan operasi perusahaan, tingkat efisiensi yang diperoleh berkaitan pada pendapatan yang dihasilkan oleh perusahaan perbankan tersebut (Defri, 2012). Hasil penelitian sebelumnya oleh Yogi dan Ramantha (2013) dan Harun (2016) menunjukkan bahwa rasio BOPO berpengaruh negatif terhadap ROA bank. Semakin efisien suatu bank dalam menjalankan bisnisnya yang ditandai dengan pendapatan operasional yang lebih besar daripada biaya operasional, maka ROA akan meningkat (Masdupi, 2014). Dengan demikian, hipotesis yang diperoleh dalam penelitian ini adalah sebagai berikut.

$\mathrm{H}_{1}$ : Rasio BOPO berpengaruh negatif pada profitabilitas perusahaan perbankan.

Laporan tahunan yang memberikan informasi mengenai profitabilitas perusahaan saat ini dianggap kurang memadai untuk menginformasikan kinerjanya karena terdapat hal-hal yang seharusnya dilaporkan kepada pengguna laporan tahunan, yaitu nilai lebih yang dimiliki oleh perusahaan. Perusahaan perbankan melakukan pengungkapan modal intelektual agar mempunyai karakteristik atau keunggulan kompetitif sehingga akan bermuara pada peningkatan profitabilitas (Rupert, 1998). Ulum (2009: 94) menyatakan bahwa apabila modal intelektual merupakan sumber daya yang terukur untuk 
peningkatan keunggulan kompetitif, maka modal intelektual akan memberikan kontribusi pada profitabilitas perusahaan.

Hasil penelitian Tan et al. (2007) menyatakan bahwa profitabilitas perusahaan positif signifikan dipengaruhi oleh modal intelektual. Menurut Ozkan et al. (2016), komponen dari modal intelektual mempengaruhi profitabilitas secara signifikan berpengaruh positif. Hal tersebut menunjukkan pengelolaan modal intelektual yang baik, maka perusahaan dapat menciptakan value added yang berguna dalam peningkatan profitabilitas perusahaan. Dengan demikian, hipotesis yang diperoleh dalam penelitian ini adalah sebagai berikut:

$\mathrm{H}_{2}$ : Modal intelektual berpengaruh positif pada profitabilitas perusahaan perbankan.

World Business Council for Sustainable Develeopment (WBCSD) mendefinisikan CSR sebagai komitmen bisnis yang berkelanjutan untuk berperilaku etis dan berkontribusi terhadap pembangunan ekonomi dengan meningkatkan kualitas kehidupan kerja karyawan, komunitas lokal, dan masyarakat yang luas (www.wbcsd.org). Perusahaan akan mengungkapkan suatu informasi jika informasi tersebut meningkatkan nilai perusahaan yang dilihat dari perspektif ekonomi seperti profitabilitas. Adanya kesadaran beberapa perusahaan akan dampak yang terjadi pada lingkungan tempat mereka menjalankan operasi perusahaannya, menimbulkan suatu tanggung jawab sosial perusahaan terhadap stakeholder.

Keterkaitan pengungkapan CSR terhadap perhatian pelanggan perusahaan perbankan sangat erat. Ketertarikan pelanggan terhadap bank akan berdampak pada penggunaan jasa keuangan yang akan menciptakan laba perusahaan 
meningkat. Mengaplikasikan tanggung jawab secara sukarela mengakibatkan produktivitas untuk mengembangkan kemampuan menarik sumber daya manusia meningkat dalam jumlah yang besar dan adanya keuntungan karena konsumen mungkin sangat sensitif terhadap isu-isu sosial dan mengurangi biaya yang diharapkan dapat memengaruhi hubungan dengan kreditur yang potensial.

Aktivitas CSR yang dilakukan oleh perusahaan akan berdampak terhadap kinerja perusahaan. Hal ini karena diduga aktivitas CSR dapat menjadi elemen yang menguntungkan sebagai strategi perusahaan, memberikan kontribusi kepada manajemen risiko dan memelihara hubungan yang dapat menghasilkan keuntungan jangka panjang bagi perusahaan. Pengungkapan CSR memberikan kontribusi bagi perusahaan dalam menciptakan laba.

Berdasarkan penelitian Karjaya dan Sisdyani (2014) dan Rosdwianti dkk. (2016) mengungkapkan bahwa CSR berpengaruh positif terhadap profitabilitas perusahaan. Perusahaan akan bertumbuh baik dengan melakukan CSR dan lebih mendapatkan respect daripada perusahaan yang tidak melakukan CSR. Berdasarkan uraian di atas, dapat diketahui bahwa dengan mengungkapkan CSR akan memberikan pengaruh pada profitabilitas perusahaan. Dengan demikian, hipotesis yang diperoleh dalam penelitian ini adalah sebagai berikut.

$\mathrm{H}_{3}$ : Pengungkapan corporate social responsibility berpengaruh positif pada profitabilitas perusahaan perbankan.

\section{METODE PENELITIAN}

Lokasi penelitian ini adalah perusahaan perbankan yang terdaftar di BEI periode 2013-2017. Data yang diperlukan diakses dengan mengunduh data dari situs resmi 
BEI yaitu www.idx.co.id. Penggunaan data dipilih pada BEI karena merupakan platform yang memberikan informasi lengkap mengenai perkembangan data-data perusahaan publik. Alasan peneliti memilih perusahaan perbankan dikarenakan fenomena yang berkaitan dengan masing-masing variabel yang akan diteliti.

Populasi yang digunakan dalam penelitian ini adalah seluruh perusahaan perbankan yang terdaftar di BEI periode 2013-2017 yaitu sebanyak 45 perusahaan. Metode penentuan sampel dalam penelitian ini menggunakan metode nonprobability sampling dengan teknik purposive sampling. Teknik analisis data yang digunakan dalam penelitian ini adalah analisis regresi linear berganda. Persamaan analisis regresi linear berganda yang digunakan adalah sebagai berikut:

$Y=\alpha+\beta_{1} \cdot X_{1}+\beta_{2} \cdot X_{2}+\beta_{3} \cdot X_{3}+e$

Keterangan:

Y : Profitabilitas

$\alpha \quad$ : Nilai konstanta

$\beta_{1} \quad$ : Koefisien regresi rasio BOPO

$\beta_{2} \quad$ : Koefisien regresi modal intelektual

$\beta_{3} \quad$ : Koefisien regresi pengungkapan corporate social responsibility

$X_{1} \quad$ : Rasio BOPO

$X_{2} \quad$ : Modal intelektual

$X_{3} \quad$ : Pengungkapan corporate social responsibility

e $\quad$ : Standar error

\section{HASIL DAN PEMBAHASAN}

Hasil penelitian ini diperoleh melalui uji statistik deskriptif, uji asumsi klasik, analisis regresi linear berganda, uji koefisien determinasi, uji kelayakan model, dan uji hipotesis. Adapun hasil uji statistik deskriptif penelitian ini disajikan tabel 2 berikut: 
Tabel 2.

Hasil Uji Statistik Deskriptif

Statistics

\begin{tabular}{lccccc}
\hline & $\mathrm{N}$ & Minimum & Maximum & Mean & Std. Deviation \\
\hline ROA & 60 & 0,002 & 0,022 & 0,01117 & 0,005289 \\
BOPO & 60 & 0,776 & 0,978 & 0,88150 & 0,054930 \\
VAIC & 60 & 4,106 & 21,511 & 5,56556 & 2,786127 \\
CSRI & 60 & 0,033 & 0,615 & 0,23443 & 0,153788 \\
Valid N (listwise) & 60 & & & &
\end{tabular}

Berdasarkan Tabel 2 terdapat berbagai informasi deskripsi dari variabel penelitian yang digunakan. Hasil uji statistik deskriptif menunjukkan jumlah sampel yang digunakan sebanyak $60(\mathrm{~N})$. Profitabilitas dalam penelitian ini diukur dengan rasio return on assets (ROA). Berdasarkan Tabel 2, ROA yang mengukur variabel profitabilitas ini memiliki nilai minimum sebesar 0,002 , sedangkan nilai maksimum dari ROA sebesar 0,022. Variabel profitabilitas menunjukkan nilai rata-rata sebesar 0,01117 . Hal tersebut menunjukkan nilai rata-rata cenderung mendekati nilai minimum yang berarti bahwa rata-rata perusahaan memiliki ROA yang rendah. Nilai standar deviasi atas ROA sebesar 0,005289.

Penelitian ini menggunakan variabel rasio BOPO. Berdasarkan Tabel 2, rasio $\mathrm{BOPO}$ memiliki nilai minimum sebesar 0,776 , sedangkan nilai maksimum dari rasio BOPO sebesar 0,978. Variabel ini menunjukkan nilai rata-rata sebesar 0,88150. Hal tersebut menunjukkan nilai rata-rata cenderung mendekati nilai minimum yang berarti bahwa rata-rata perusahaan memiliki rasio BOPO yang rendah. Nilai standar deviasi atas rasio BOPO sebesar 0,054930.

Modal intelektual dalam penelitian ini diukur dengan value added intellectual coefficient $\left(\mathrm{VAIC}^{\mathrm{TM}}\right)$. Berdasarkan Tabel 2, VAIC ${ }^{\mathrm{TM}}$ yang mengukur variabel modal intelektual ini memiliki nilai minimum sebesar 4,106, sedangkan 
nilai maksimum dari $\mathrm{VAIC}^{\mathrm{TM}}$ sebesar 21,511. Variabel modal intelektual menunjukkan nilai rata-rata sebesar 5,56556. Hal tersebut menunjukkan nilai ratarata cenderung mendekati nilai maksimum yang berarti bahwa rata-rata perusahaan memiliki $\mathrm{VAIC}^{\mathrm{TM}}$ yang tinggi. Nilai standar deviasi atas $\mathrm{VAIC}^{\mathrm{TM}}$ sebesar 2,786127 .

Pengungkapan corporate social responsibility (CSR) dalam penelitian ini diukur dengan corporate social responsibility disclosure index (CSRI). Berdasarkan Tabel 2, CSRI yang mengukur variabel pengungkapan CSR ini memiliki nilai minimum sebesar 0,033 , sedangkan nilai maksimum dari CSRI sebesar 0,615. Variabel pengungkapan CSR menunjukkan nilai rata-rata sebesar 0,23443. Hal tersebut menunjukkan nilai rata-rata cenderung mendekati nilai maksimum yang berarti bahwa rata-rata perusahaan memiliki CSRI yang tinggi. Nilai standar deviasi atas CSRI sebesar 0,153788. Nilai standar deviasi atas masing-masing variabel memiliki nilai lebih rendah dari nilai nilai rata-rata berarti bahwa hasil penyebaran data profitabilitas, rasio BOPO, modal intelektual, dan pengungkapan CSR sudah merata atau rentang data satu dengan data yang lainnya tidak tergolong tinggi dan tergolong normal serta tidak menyebabkan bias. 
Hasil uji normalitas penelitian ini disajikan tabel 3 berikut:

Tabel 3.

Hasil Uji Normalitas

One-Sample Kolmogorov-Smirnov Test

\begin{tabular}{|c|c|c|}
\hline & & Unstandardized Residual \\
\hline $\mathrm{N}$ & & 60 \\
\hline \multirow[t]{2}{*}{ Normal Parameters ${ }^{\mathrm{a}, \mathrm{b}}$} & Mean & 0,0000000 \\
\hline & Std. Deviation & 0,00204375 \\
\hline \multirow[t]{3}{*}{ Most Extreme Differences } & Absolute & 0,108 \\
\hline & Positive & 0,108 \\
\hline & Negative & $-0,090$ \\
\hline Kolmogorov-Smirnov Z & & 0,834 \\
\hline Asymp. Sig. (2-tailed) & & 0,490 \\
\hline
\end{tabular}

Sumber: Data diolah, 2018

Berdasarkan Tabel 3 menunjukkan nilai Asymp. Sig. (2-tailed) dari model persamaan yang diuji sebesar 0,490 yakni lebih besar dari 0,05. Hal ini menunjukkan data yang digunakan dalam penelitian ini telah berdistribusi normal.

Hasil uji autokorelasi penelitian ini disajikan tabel 4 berikut:

Tabel 4.

Hasil Uji Autokorelasi

Model Summary ${ }^{b}$

\begin{tabular}{cccccc}
\hline Model & $\mathrm{R}$ & $\mathrm{R}$ Square & $\begin{array}{c}\text { Adjusted R } \\
\text { Square }\end{array}$ & $\begin{array}{c}\text { Std. Error of } \\
\text { the Estimate }\end{array}$ & $\begin{array}{c}\text { Durbin- } \\
\text { Watson }\end{array}$ \\
\hline 1 & $0,922^{\mathrm{a}}$ & 0,851 & 0,843 & 0,002098 & 2,061 \\
\hline \multicolumn{2}{l}{ Sumber: Data diolah, 2018} & & & &
\end{tabular}

Berdasarkan Tabel 4 menunjukkan nilai DW yang dihasilkan sebesar 2,061. Sedangkan dari tabel DW dengan signifikansi 0,05 dan jumlah data $N=60$ serta $\mathrm{k}=3$ diperoleh nilai $\mathrm{dL}$ sebesar 1,4797 dan dU sebesar 1,6889. Nilai DW sebesar 2,061 terletak antara batas atas dU sebesar 1,6889 dan 4-dU sebesar 2,3111 sehingga koefisien autokorelasi sama dengan nol berarti tidak ada autokorelasi. 
Hasil uji multikolinearitas penelitian ini disajikan tabel 5 berikut:

Tabel 5.

Hasil Uji Multikolinearitas Coefficients $^{\mathrm{a}}$

\begin{tabular}{llcc}
\hline Model & & \multicolumn{2}{c}{ Collinearity Statistics } \\
\cline { 3 - 4 } & & Tolerance & VIF \\
\hline 1 & BOPO & 0,559 & 1,789 \\
& VAIC & 0,608 & 1,645 \\
& CSRI & 0,898 & 1,113 \\
\hline
\end{tabular}

Sumber: Data diolah, 2018

Berdasarkan Tabel 5 menunjukkan bahwa nilai tolerance dan VIF dari variabel rasio BOPO, variabel modal intelektual yang diukur dengan $\mathrm{VAIC}^{\mathrm{TM}}$, dan variabel pengungkapan corporate social responsibility yang diukur dengan CSRI memiliki nilai tolerance untuk setiap variabel lebih besar dari 10 persen dan nilai VIF lebih kecil dari 10 yang berarti model persamaan regresi bebas dari multikolinearitas.

Hasil uji heteroskedastisitas penelitian ini disajikan tabel 6 berikut:

Tabel 6.

Hasil Uji Heteroskedastisitas

Coefficients $^{\mathrm{a}}$

\begin{tabular}{llc}
\hline Model & & Sig. \\
\hline 1 & BOPO & 0,060 \\
& VAIC $^{\text {TM }}$ & 0,896 \\
& CSRI & 0,056 \\
\hline
\end{tabular}

Sumber: Data diolah, 2018

Berdasarkan Tabel 6 menunjukkan bahwa masing-masing nilai signifikansi dari variabel lebih besar 0,05 yang berarti bahwa seluruh variabel pada penelitian ini tidak mengandung atau bebas dari heteroskedastisitas.

Hasil analisis regresi linear berganda penelitian ini disajikan tabel 7 berikut: 
Tabel 7.

Hasil Analisis Regresi Linear Berganda Coefficients $^{\mathrm{a}}$

\begin{tabular}{llccccc}
\hline \multirow{2}{*}{ Model } & \multicolumn{2}{c}{ Unstandardized Coefficients } & $\begin{array}{c}\text { Standardized } \\
\text { Coefficients }\end{array}$ & $\mathrm{t}$ & \multirow{2}{*}{ Sig. } \\
\cline { 2 - 4 } & \multicolumn{2}{c}{$\mathrm{B}$} & Std. Error & Beta & & \\
\hline 1 & (Constant) & 0,09002 & 0,00561 & & 16,035 & 0,000 \\
& BOPO & $-0,08806$ & 0,00665 & $-0,91458$ & $-13,242$ & 0,000 \\
& VAIC & $-0,00009$ & 0,00013 & $-0,04818$ & $-0,727$ & 0,470 \\
& CSRI & $-0,00305$ & 0,00187 & $-0,08882$ & $-1,630$ & 0,109 \\
\hline
\end{tabular}

Berdasarkan Tabel 7, maka persamaan regresi dalam penelitian ini yaitu:

$$
\mathrm{Y}=0,09002-0,08806 \mathrm{X}_{1}-0,00009 \mathrm{X}_{2}-0,00305 \mathrm{X}_{3}+\mathrm{e}
$$

Nilai konstanta $(\alpha)$ sebesar 0,09002 artinya jika nilai profitabilitas yang diproksikan dengan ROA konstan, maka nilai profitabilitas (Y) cenderung meningkat sebesar 0,09002 satuan. Nilai koefisien regresi $\left(\beta_{1}\right)$ dari variabel rasio BOPO $\left(\mathrm{X}_{1}\right)$ sebesar $-0,08806$ artinya apabila rasio BOPO mengalami penurunan sebesar satu satuan, maka profitabilitas (Y) meningkat sebesar 0,08806 satuan dengan asumsi variabel lainnya konstan. Nilai koefisien regresi $\left(\beta_{2}\right)$ dari variabel modal intelektual $\left(\mathrm{X}_{2}\right)$ sebesar $-0,00009$ artinya apabila nilai variabel modal intelektual yang diproksikan dengan $\mathrm{VAIC}^{\mathrm{TM}}$ mengalami kenaikan sebesar satu satuan, maka profitabilitas (Y) menurun sebesar 0,00009 satuan dengan asumsi variabel lainnya konstan. Nilai koefisien regresi $\left(\beta_{3}\right)$ dari variabel pengungkapan corporate social responsibility $\left(\mathrm{X}_{3}\right)$ sebesar $-0,00305$ artinya apabila nilai variabel corporate social responsibility yang diproksikan dengan CSRI mengalami kenaikan sebesar satu satuan, maka profitabilitas (Y) menurun sebesar 0,00305 satuan dengan asumsi variabel lainnya konstan. 
Hasil uji koefisien determinasi penelitian ini disajikan tabel 8 berikut:

Tabel 8.

Hasil Uji Koefisien Determinasi Model Summary ${ }^{\mathrm{b}}$

\begin{tabular}{lcccc}
\hline Model & $\mathrm{R}$ & $\mathrm{R}$ Square & $\begin{array}{c}\text { Adjusted R } \\
\text { Square }\end{array}$ & $\begin{array}{c}\text { Std. Error of the } \\
\text { Estimate }\end{array}$ \\
\hline 1 & $0,922^{\mathrm{a}}$ & 0,851 & 0,843 & 0,002098 \\
\hline Sumber: Data diolah, 2018 & & &
\end{tabular}

Berdasarkan Tabel 8 menunjukkan bahwa nilai Adjusted $R^{2}$ sebesar 0,843 yang artinya bahwa 84,3 persen variasi profitabilitas dipengaruhi oleh variasi pada variabel rasio $\mathrm{BOPO}$, modal intelektual, dan pengungkapan corporate social responsibility, sedangkan sisanya 15,7 persen dipengaruhi oleh variabel lainnya yang tidak dimasukkan dalam model yang digunakan pada persamaan.

Hasil uji kelayakan model penelitian ini disajikan tabel 9 berikut:

Tabel 9.

Hasil Uji Kelayakan Model

ANOVA $^{\mathrm{b}}$

\begin{tabular}{llccccc}
\hline Model & & $\begin{array}{c}\text { Sum of } \\
\text { Squares }\end{array}$ & Df & $\begin{array}{c}\text { Mean } \\
\text { Square }\end{array}$ & F & Sig. \\
\hline 1 & Regression & 0,001 & 3 & 0,000 & 106,349 & $0,000^{\mathrm{a}}$ \\
& Residual & 0,000 & 56 & 0,000 & & \\
& Total & 0.002 & 59 & & & \\
\hline
\end{tabular}

Sumber: Data diolah, 2018

Berdasarkan Tabel 9 menunjukkan bahwa nilai Sig. F yakni 0,000 lebih kecil dari $\alpha=0,05$. Hal tersebut berarti bahwa model penelitian ini layak digunakan sebagai alat analisis pengujian pengaruh variabel bebas pada variabel terikat. 
Hasil uji hipotesis penelitian ini disajikan tabel 10 berikut:

Tabel 10.

Hasil Uji Hipotesis

Coefficients $^{\text {a }}$

\begin{tabular}{llccccc}
\hline Model & \multicolumn{3}{c}{ Unstandardized Coefficients } & $\begin{array}{c}\text { Standardized } \\
\text { Coefficients }\end{array}$ & t & Sig. \\
\cline { 2 - 4 } & \multicolumn{2}{c}{$\mathrm{B}$} & Std. Error & Beta & & \\
\hline 1 & (Constant) & 0,09002 & 0,00561 & & 16,035 & 0,000 \\
& BOPO & $-0,08806$ & 0,00665 & $-0,91458$ & $-13,242$ & 0,000 \\
& VAIC & $-0,00009$ & 0,00013 & $-0,04818$ & $-0,727$ & 0,470 \\
\multicolumn{2}{l}{ CSRI } & $-0,00305$ & 0,00187 & $-0,08882$ & $-1,630$ & 0,109 \\
\hline \multicolumn{2}{l}{ Sumber: Data diolah, 2018 }
\end{tabular}

Berdasarkan Tabel 10 menunjukkan bahwa hasil uji hipotesis adalah sebagai berikut: (1) Variabel rasio BOPO memiliki nilai signifikansi uji t sebesar $0,000 \leq 0,05$ serta nilai koefisien regresi sebesar $-0,08806$. Hal ini berarti bahwa rasio BOPO berpengaruh negatif dan signifikan pada profitabilitas perusahaan perbankan, sehingga $\mathrm{H}_{0}$ ditolak dan $\mathrm{H}_{1}$ diterima. (2) Variabel modal intelektual yang diukur dengan $\mathrm{VAIC}^{\mathrm{TM}}$ memiliki nilai signifikansi uji t sebesar $0,479 \geq 0,05$ serta nilai koefisien regresi sebesar -0,00009. Hal ini berarti bahwa modal intelektual tidak berpengaruh pada profitabilitas perusahaan perbankan, sehingga $\mathrm{H}_{0}$ diterima dan $\mathrm{H}_{2}$ ditolak. (3) Variabel pengungkapan corporate social responsibility yang diukur dengan CSRI memiliki nilai signifikansi uji t sebesar $0,109 \geq 0,05$ serta nilai koefisien regresi sebesar $-0,00305$. Hal ini berarti bahwa pengungkapan corporate social responsibility tidak berpengaruh pada profitabilitas perusahaan perbankan, sehingga $\mathrm{H}_{0}$ diterima dan $\mathrm{H}_{2}$ ditolak.

Rasio BOPO berpengaruh negatif terhadap ROA, sehingga hasil penelitian ini menunjukkan bahwa rasio BOPO yang semakin menurun, maka profitabiltas perusahaan perbankan akan semakin meningkat. Hal ini disebabkan karena dalam menjalankan operasi perusahaan, tingkat efisiensi yang diperoleh berkaitan pada 
pendapatan yang dihasilkan oleh perusahaan perbankan tersebut (Defri, 2012). Hasil penelitian sebelumnya oleh Yogi dan Ramantha (2013) dan Harun (2016) menunjukkan bahwa variabel rasio BOPO berpengaruh negatif dan signifikan terhadap profitabilitas bank yang diproksikan dengan ROA. Hal ini berarti semakin rendah rasio BOPO, maka semakin tinggi profitabilitas yang diperoleh oleh bank. Semakin efisien suatu bank dalam menjalankan bisnisnya yang ditandai dengan pendapatan operasional yang lebih besar daripada biaya operasional, maka ROA akan meningkat (Masdupi, 2014). Hal ini ditunjukkan dengan hasil rasio BOPO yang rendah dan menyebabkan profitabilitas yang diperoleh oleh bank semakin tinggi.

Berdasarkan hasil uji hipotesis yang menunjukkan bahwa modal intelektual tidak berpengaruh pada profitabilitas perusahaan perbankan dikarenakan terdapat indikasi bahwa masih kurang mendominasinya modal intelektual untuk memberikan kontribusi pada profitabilitas perusahaan perbankan. Selain itu, masih adanya kebijakan dari masing-masing perusahaan yang kurang mendukung penciptaan $\mathrm{VAIC}^{\mathrm{TM}}$. Berdasarkan fenomena, bank kurang mengandalkan modal intelektualnya dalam meningkatkan profitabilitas.

Perusahaan perbankan memiliki sumber daya manusia yang sudah menerapkan proses rutinitas perusahaan dengan terstruktur, berteknologi, bekerja dengan mekanisme yang optimal, dan sistem operasional yang memadai serta sehingga menjadikan modal intelektual belum menjadi suatu keunggulan daya saing yang unik dalam arti bahwa perusahaan belum memiliki aset strategis yang sulit untuk ditiru karena hal tersebut cenderung merupakan sebuah rutinitas 
perusahaan. Selain itu, modal intelektual merupakan informasi dari perusahaan yang masih abstrak atau susah untuk dijelaskan melalui perhitungan pasti atau matematis, sehingga pengukuran untuk besarnya modal intelektual masih belum akurat.

Penelitian ini didukung dengan penelitian Ciptaningsih (2013) dan Damayanti (2015) yang menyatakan bahwa modal intelektual dengan proksi VAIC $^{\mathrm{TM}}$ tidak berpengaruh pada ROA perusahaan. Tidak sejalan pula dengan penelitian Baroroh (2013) yang membuktikan bahwa modal intelektual berpengaruh positif pada ROA. Namun, diketahui dari hasil deskriptif menjelaskan masing-masing indikator dari $\mathrm{VAIC}^{\mathrm{TM}}$, indikator yang dominan adalah hanya VAHC. Perusahaan masih hanya memperhatikan salah satu indikator saja sedangkan dalam teori resource-based menyebutkan untuk memperoleh keunggulan kompetitif diperlukan aset startegis seperti modal intelektual secara baik dari ketiga indikator agar dapat meningkatkan profitabilitas perusahaan perbankan.

Berdasarkan hasil uji hipotesis yang menunjukkan bahwa pengungkapan CSR tidak berpengaruh pada profitabilitas perusahaan perbankan yang diproksikan dengan ROA. Hal ini menunjukkan bahwa indeks pengungkapan CSR perusahaan yang semakin tinggi, tidak memiliki pengaruh signifikan pada peningkatan pengembalian aset untuk operasional atau perolehan ROA perusahaan. Hasil penelitian ini didukung dengan penelitian Mustafa dan Handayani (2014) dan Yaparto dkk. (2013) yang menyatakan bahwa pengungkapan CSR tidak memiliki pengaruh terhadap ROA perusahaan. Hal 
tersebut didukung pula dengan pernyataan bahwa kegiatan CSR menimbulkan biaya bagi perusahaan sehingga dapat mengurangi laba perusahaan. Apabila peningkatan aset tidak diimbangi dengan peningkatan laba, maka akan mengakibatkan penurunan ROA perusahaan.

Selain itu, adanya kecenderungan perusahaan perbankan membuat birokrasi tambahan terkait bidang CSR sehingga meningkatkan biaya ketaatan. Kinerja pengelolaan CSR pula hanya ditinjau dari segi anggaran, bukan kemandirian masyarakat yang dirasakan dari komitmen perusahaan. Hal itu dapat ditunjukkan pada laporan tahunan bagian pelaporan CSR sebagian besar perusahaan perbankan merealisasikan dengan memberikan sumbangansumbangan pada kegiatan insidental yang belum memiliki dampak keberlanjutan. Hal tersebut pula menunjukkan ketidaksesuaian dengan salah satu prinsip yang dikemukakan Bank Dunia yaitu CSR bukanlah sebuah sumbangan.

\section{SIMPULAN}

Berdasarkan hasil penelitian mengenai pengaruh rasio BOPO, modal intelektual, dan pengungkapan corporate social responsibility pada profitabilitas perusahaan perbankan, dapat disimpulkan bahwa rasio BOPO berpengaruh negatif pada profitabilitas perusahaan perbankan. Selain itu, modal intelektual dan pengungkapan corporate social responsibility tidak berpengaruh pada profitabilitas perusahaan perbankan.

Berdasarkan hasil dan pembahasan serta simpulan pada penelitian ini, adapun saran-saran yang dapat diberikan dalam penelitian ini, yaitu peneliti 
selanjutnya diharapkan menggunakan variabel dan proksi lain, menambah jumlah perusahaan yang diteliti, menganalisis pengaruh jangka panjang pada variabel modal intelektual dan pengungkapan CSR, melakukan pengembangan penelitian pada variabel modal intelektual dengan meneliti masing-masing indikator modal intelektual yang terdiri dari VACE, VAHC, dan VASC, serta menggunakan laporan keberlanjutan perusahaan atau sustainability reporting yang telah di cross check oleh Global Reporting Initiative agar mengurangi risiko subjektivitas penilaian indeks pengungkapan CSR.

\section{REFERENSI}

Bank Indonesia (BI). Undang-Undang RI Nomor 10 Tahun 1998. 10 November 1998 tentang Perbankan. (1998). www.bi.go.id. Diakses 16 Juli 2018.

Baroroh, N. (2013). Analisis Pengaruh Modal Intelektual terhadap Kinerja Keuangan Perusahaan Manufaktur di Indonesia. Jurnal Dinamika Akuntansi, 5(2), 172-182.

Bhernadha, Yhovita Anggie, Topowijono, dan D. F. A. (2017). Pengaruh Corporate Social Responsibility terhadap Kinerja Keuangan Perusahaan (Studi pada Perusahaan Winner of Sustainability Reporting Award (Sra) 2015 yang Terdaftar Di PT BEI Periode 2010-2014). Jurnal Administrasi Bisnis, 44(1), 134-143.

Bontis, Nick., Stevo Janošević, and V. D. (2015). Intellectual Capital in Serbia's Hotel Industry. International Journal of Contemporary Hospitality Management, 27(6), 1365-1384.

Ciptaningsih, T. (2013). Uji Pengaruh Modal Intelektual Terhadap Kinerja Keuangan BUMN yang Go Public di Indonesia. Jurnal Manajemen Teknologi, 13(3), 2089-7928.

Damayanti, C. (2015). Pengaruh Modal Intelektual Terhadap Kinerja Keuangan Perusahaan Perbankan yang Terdaftar di Bursa Efek Indonesia (BEI) Tahun 2010-2013. Skripsi Jurusan Akuntansi Sekolah Tinggi Ilmu Ekonomi Perbanas Surabaya. 
Defri. (2012). Pengaruh Capital Adequacy Ratio (CAR), Likuiditas, dan Efisiensi Operasional Terhadap Profitabilitas Perusahaan Perbankan yang Terdaftar di BEI. Jurnal Manajemen, 1(1), 1-18.

DeSarbo, Wayne S., C. Anthony Di Benedetto, Michael Song, and I. S. (2005). Revisiting the Miles and Snow Strategic Framework: Uncovering Interrelationships between Strategic Types, Capabilities, Environmental Uncertainty, and Firm Performance. Strategic Management Journal, 26, 4774.

Fariana, Rina. (2014). Pengaruh Value Added Capital Employed (VACA), Value Added Human Capital (VAHU), dan Structural Capital Value Added (STVA) Terhadap Kinerja Keuangan Perusahaan Jasa Keuangan yang Go Public di Indonesia. Majalah Ekonomi. XVIII.

Gray, Rob, Reza Kouhy, and S. L. (1995). Corporate Social and Environmental Reporting A Review of the Literature and A Longitudinal Study of UK Disclosure. Accounting, Auditing \& Accountability Journal, 8(2), 47-76.

Harfiah, Laila Mugi, Atiek Sri Purwati, and P. U. (2016). The Impact of ROA, BOPO, and FDR to Indonesian Islamic Bank's Mudharabah Deposit Profit Sharing. Etikonomi, 15(1), 19-30.

Harun, U. (2016). Pengaruh Ratio-Ratio Keuangan CAR, LDR, NIM, BOPO, NPL terhadap ROA. Jurnal Riset Bisnis Dan Manajemen, 4(1), 67-82.

Hendra Karjaya, I. W. dan E. A. S. (2014). Pengaruh Tingkat Pengungkapan CSR dan Mekanisme GCG pada Kinerja Keuangan Perusahaan Pertambangan. EJurnal Akuntansi Universitas Udayana ISSN : 2302-8556, 8(3), 620-629.

Jackson, S. E. dan R. S. S. (1995). Understanding Human Resource Management in The Context Of Organizations and Their Environment. Annual Review of Psychology, 46(1), 237-264.

Khalique, Muhammad., Jamal Abdul Nassir bin Shaari, Abu Hassan bin Md. Isa, and N. binti S. (2013). Impact of Intellectual Capital on the Organizational Performance of Islamic Banking Sector in Malaysia. Asian Journal of Finance and Accounting, 5(2), 75-83.

Kweh, Qian Long., Y. C. C. and I. W. K. T. (2013). Measuring Intellectual Capital Efficiency In The Malaysian Sofware Sector. Journal of Intellectual Capital, 14(2), 310-324.

Lentjushenkova, O. dan I. L. (2014). The Classification of the Intellectual Capital Investments of an Enterprise. Procedia - Social and Behavioral Sciences, 
$156,53-57$.

Lia Victoria, N. P. dan N. M. A. E. (2015). Pengaruh Rasio Keuangan dan Non Keuangan pada Kinerja Keuangan Perbankan. E-Jurnal Akuntansi Universitas Udayana, 13(2), 625-642.

Limpaphayom, Piman, dan S. P. (2004). Bank Relationship and Firm Performance: Evidence from Thailand before The Asian Financial Crisis. Journal of Business Finance and Accounting.

Maesaroh, S. dan Y. R. (2015). Pengaruh Modal Intelektual terhadap Kinerja Keuangan pada Perusahaan Manufaktur. Jurnal Ilmu Dan Riset Akuntansi, 4(11), 1-18.

Masdupi, E. (2014). Pengaruh Efisiensi Operasional Terhadap Profitabilitas Sektor Perbankan. Jurnal Kajian Manajemen Bisnis, 3(1), 121-138.

Mustafa, C. C. dan N. H. (2014). Pengaruh Pengungkapan Corporate Social Responsibility Terhadap Kinerja Keuangan Perusahaan Manufaktur. Jurnal Ilmu Dan Riset Akuntansi, 3(6), 1-16.

Ngoc, N. B. (2018). The Effect of Corporate Social Responsibility Disclosure on Financial Performance: Evidence from Credit Institutions in Vietnam. Asian Social Science, 14(4), 109-122.

Nursatyani, A. (2011). Analisis Pengaruh Efisiensi Operasi, Risiko Kredit, Risiko Pasar, dan Modal terhadapa Kinerja Keuangan Perbankan (Studi Perbandingan pada Bank Domestik dan Bank Asing di Indonesia Periode 2004-2008). Skripsi Sarjana Fakultas Ekonomi Universitas Diponegoro.

O'Donovan, G. (2002). Environmental Disclosures in the Annual Report: Extending the Applicability and Predictive Power of Legitimacy Theory. Accounting, Auditing and Accountability Journal, 15(2), 344-371.

Ozkan, Nasif, Sikan Cakan, D., \& Murad Kayacan. (2016). Intellectual Capital and Financial Performance: A Study of Turkish Banking Sector. Borsa Istanbul Review, 17(3), 190-198.

Pulic, A. (1998). Measuring The Performance of Intellectual Potential In Knowledge Economy. Paper Presented at the $2^{\text {nd }}$ McMaster and Managing Intellectual Capital by The Austrian Team for Intellectual Capital Potential. Available Online at: www.vaic-on.net. Diakses 24 November 2017.

Puspitosari, I. (2016). Pengaruh Modal Intelektual terhadap Kinerja Keuangan pada Sektor Perbankan. Jurnal EBBANK, 7(1), 43-53. 
Rehman, Wasim ul, M.Ilyas, and H. U. R. (2011). Intellectual Capital Performance and Its Impact on Financial Returns of Companies: An Empirical Study from Insurance Sector of Pakistan. African Journal of Business Management, 5(20), 8041-8049.

Rosdwianti, Mega Karunia, Moch. Dzulkirom AR., dan Z. Z. A. (2016). Pengaruh Corporate Social Responsibility (CSR) Terhadap Profitabilitas Perusahaan. Jurnal Administrasi Bisnis, 38(2), 16-22.

Rupert, Booth. (1998). The Measurement of Intellectual Capital. Management Accounting, 76, 26-28.

Salim, S. M. dan G. K. (2013). Pengaruh Modal Intelektual Terhadap Kinerja Keuangan. Journal Of Business and Entrepreneurship, 1(2), 74-91.

Sandy, Kunthi Fahmar. (2018). Tingginya Bunga Kredit Bank Ancam Gerus Daya Saing Produk Lokal. Diunduh dari: https://ekbis.sindonews.com/read/1333 663/178/ tingginya-bunga-kredit bank-ancam-gerus-daya-saing-produk-lokal-1535440824. Diakses 19 September 2018.

Sari, Wahyu Aprilia Sari, Siti Ragil Handayani, dan N. F. N. (2016). Pengaruh Pengungkapan Corporate Social Responsibility Terhadap Kinerja Keuangan dan Nilai Perusahaan (Studi Komparatif pada Perusahaan Multinasional yang Terdaftar di Bursa Efek Indonesia dan Bursa Malaysia Tahun 2012-2015). Jurnal Administrasi Bisnis, 39(2), 74-83.

Sofiyan, Basir. (2013). Commersial Bank Management:Manajemen Perbankan Dari Teori Ke Praktik. Jakarta: Rajawali Pers.

Solikhah, Badingatus, H. Abdul Rohman, dan W. M. (2010). Implikasi Intellectual Capital Terhadap Financial Performance, Growth Dan Market Value; Studi Empiris Dengan Pendekatan Simplistic Spesification. Makalah Simposium Nasional Akuntansi XIII, 1-29.

Suryaman, Y. W. S. (2016). Peran dan Tanggungjawab Perbankan Dalam Implementasi Green Banking. Prosiding SENTIA, 8, 36-42.

Tan, Hong Pew., D. P. and P. H. (2007). Intellectual Capital and Financial Returns of Companies. Journal of Intellectual Capital, 8(1), 76-95.

Ulum, Ihyaul, Imam Ghozali, D., \& Anis Chariri. (2008). Intellectual Capital Dan Kinerja Keuangan Perusahaan; Suatu Analisis Dengan Pendekatan Partial Least Squares. Jurnal Akuntansi Dan Investasi, 19(19), 23-24. 
Ulum, Ihyaul. (2009). Intellectual Capital: Konsep dan Kajian Empiris. Yogyakarta: Graha Ilmu.

Untara, A. P. dan T. M. (2014). Pengaruh Modal Intelektual terhadap Kinerja Keuangan Perusahaan Perbankan yang Terdaftar di BEI. Jurnal Ilmu Dan Riset Akuntansi, 3(10), 1-15.

Winarno, Lina Nur Hidayati, dan A. D. (2015). Faktor-Faktor yang Memengaruhi Profitabilitas Perusahaan Manufaktur yang Listed di Bursa Efek Indonesia. Jurnal Economia, 11(2), 143-149.

World Bank Group. (2018). IFC Cements Partnership with Indonesia's Financial Services Authority (OJK) to Advance Global Sustainable Finance. Diunduh dari: www.ifc.org. Diakses 19 September 2018.

World Business Council for Sustainable Develeopment (WBCSD). (2017). Definition of Corporate Social Responsibility. Diunduh dari: www.wbcsd.org. Diakses 8 Agustus 2018.

Yaparto, Marissa, Dianne Frisko, dan R. E. (2013). Pengaruh Corporate Social Responsibility terhadap Kinerja Keuangan pada Sektor Manufaktur yang Terdaftar Di Bursa Efek Indonesia pada Periode 2010-2011. Jurnal Imiah Mahasiswa Universitas Surabaya, 2(1), 1-19.

Yogi Prasanjaya, A. A. dan I. W. R. (2013). Analisis Pengaruh Rasio CAR, BOPO, LDR, dan Ukuran Perusahaan terhadap Profitabilitas Bank yang Terdaftar di BEI. E-Jurnal Akuntansi Universitas Udayana, 4(1), 230-245. 